\title{
PLUS ÇA CHANGE
}

\section{From Postprocessualism to "Big Data"}

\author{
Elizabeth S. Chilton
}

\author{
UMass Amherst \\ College of Social \& Behavioral Sciences \\ Center for Heritage \& Society \\ echilton@anthro.umass.edu
}

I appreciate the opportunity to comment on Kristiansen's provocative keynote article, “Towards a New Paradigm? The Third Science Revolution and Its Possible Consequences in Archaeology." The main argument put forth by Kristiansen is that archaeology is moving out of a "postmodern/postprocessual hegemony, and ...[towards] a revised modern/processual approach." In the wake of the presumed collapse of postprocessualism he points to the rise of "big data" and "big funding" for archaeology. The latter he characterizes as having led to the disappearance of the boundary between science and humanities and between theory and data. While there is no doubt that new technological innovations and sources of funding will have a direct and profound impact on archaeology - as other disciplines - in this short response I wish to highlight where I diverge from Kristiansen's perspective in three key areas: (I) the definition of postprocessual archaeology; (2) his characterization of the demise of postprocessual archaeology; and (3) his assertion that there is in fact a "third scientific revolution," which provides the answer to the future of archaeology. 


\section{DEFINING THE POSTPROCESSUAL CRITIQUE AND ITS LEGACY}

My first point of departure from Kristiansen is that he presents postprocessual archaeology in contrast to other theoretical approaches. Instead, I view it as primarily a critique of processual archaeology - specifically its idealist quest for generalizing laws of human history and behavior. Postprocessual archaeology was and is not a cohesive theoretical approach or paradigm, and proponents embrace a wide variety of theoretical perspectives: neo-Marxism, postmodernism, feminist theory, post-structuralism, critical theory, etc. As Preucel (I995:I47) puts it, "the term refers not to an unified program but, rather, to a collection of widely divergent and often contradictory research interests."

While I would not characterize postprocessual as a paradigm unto itself, there have nevertheless been a number of changes in archaeological theory and practice that grew out of the postprocessual critique and that were spawned by postmodernism more broadly. These perspectives and critiques have had several lasting and significant effects on archaeology as a whole: there is a greater acknowledgement of the subjective position of the archaeologist, a greater emphasis on the role of human agency in interpretations of the past, and a persistent call for multivocality - for including the voices, perspectives, and values of marginalized peoples (who have traditionally been the objects of study of archaeologists and anthropologists).

The postprocessual critique and debate had a profound effect on the field of archaeology - even for those who would never call themselves postprocessualists. In the U.S. most of the archaeological practice was and is in Cultural Resource Management (CRM) or compliance archaeology. Postprocessualism has probably only affected CRM archaeology to a small degree, specifically with respect to the kinds of stakeholders consulted and the more diverse array of interpretations offered (i.e., beyond subsistence). On the other hand, in academia much has changed. The types of subjects that are undertaken in archaeology include the African Diaspora, social inequality and racism, Indigenous archaeology, repatriation, and heritage values. The pursuit of new subjects has not led to the diminution of field methods, labs methods, and data management. But it has affected how we do what we do - how we create categories in our data, who we consult with and when, who we share our data with, and how we interpret our data. As Dobres (I999) argues, "even seeing empirical variability in the archaeological record ... is a learned skill." Having learned how to "see" the challenge, as she puts it, is "to explore how thinking and seeing differently can lead to potentially dif- 
ferent empirical findings and alternative understandings of the past." By highlighting agency in prehistory and in our analytical methods "seeing differently" can be labeled as postprocessual or humanistic, but it can also just be good science. Some archaeology that has been labeled as "postprocessual" was simply social scientific archaeology that focused on subjects that had been ignored by the New Archaeologists, such as social inequality (e.g., McGuire \& Paynter 199I), gender in prehistory and archaeology (e.g., Gero \& Conkey 199I), and power (e.g., Sweely I999). A new focus on such topics led not only to new data but to the development of new theoretical approaches as well.

\section{WHAT'S IN A NAME?}

If one agrees that postprocessualism was a critique - and not a paradigm - then its legacy can be left to live on, and one does not need to make a choice between it and a "new scientific paradigm." Perhaps the postprocessual critique was more agreeable to academic archaeology in the U.S. because most of us are anthropologists and very comfortable in our role as social scientists - not feeling we have to choose between natural science and humanities. When I was interviewed for my first tenure track position after receiving my $\mathrm{PhD}$ in 1996 , at the interview a tenured professor said to me "So you are from UMass. Does that mean you are a postprocessualist?" "Actually," I replied, "I am a flexible generalist." He chuckled and I then went on to describe both my theoretical and methodological work, but the point of my response is that I did not - and do not - feel it useful to categorize all archaeology as either processualist or postprocessualist, as either science or humanities. Perhaps this is a manifestation of what Preucel and Mrozowski call the "new pragmatism," that is, not the dominance of one theory but the "explicit integration of archaoelogy and its social context in ways that serve contemporary need" (2010:3). As archaeologists we know that typologies and nominal variables in general should be used only in so far as they are useful. At this point I think it is most useful to think of 2 Ist-century archaeology as a palimpsest of its own history and as inextricable with the values and priorities of the times, which includes the role of big data, a need for heritage management in the context of competing values, and a challenge to the role of the historiographical expert. If you add to this list of challenges the devaluing of science and humanities (at least in the United States), self-preservation would dictate that there is good reason to gravitate towards more scientific approaches, especially in an era where there is a renewed optimism that science will solve the world's problems. 


\section{A THIRD SCIENTIFIC REVOLUTION OR PLUS C'EST LA MÊME CHOSE?}

Does this mean we should declare a third scientific revolution in archaeology? From his brief overview of the history of archaeology Kristiansen concludes, "a wedding of aspects of materiality/thing theory and evolutionary theory is necessary in order to reassemble some of the theoretical spoils of the recent meltdown of the dominant paradigms." $\mathrm{He}$ points to the signs of a third scientific revolution in archaeology: (I) the arrival of our ability to amass and analyze "Big Data"; (2) the methodological power of quantification and modeling; and (3) the theoretical power of new knowledge. While the Internet, faster computers, and more sophisticated applications have advanced both the scale and speed of potential research avenues, I do not share his perspective on the how these advances will impact archaeological theory. Our creation and use of archaeological databases and data set is largely undertheorized. Amassing larger datasets does not remove the interpretive nature of the creation of these datasets in the first place: "what makes the archaeological data speak to us, when we interpret it, when it makes sense, is the act of placing it in a specific context or set of contexts" (Shanks and Tilley 1987:I04). Acknowledging the value-laden and context-specific nature of datasets does not stymie us from moving forward, but it does present a challenge - especially as larger and larger datasets are combined from multiple sources and contexts. As Alison Wylie (2002) puts it, "Archaeologists can and routinely do make empirically grounded and conceptually reasoned judgments about the relative credibility of claims about the evidential significance of archaeological data; these are by no means certain, but neither are they entirely arbitrary. The problem is to give a systematic account of how researchers make such judgments." In this vein, I do not see the arrival or use of big data as requiring an inevitable return to processualism - it simply continues to improve and expand the powerful toolkits that archaeologists have at their disposal.

\section{PUBLIC ARCHAEOLOGY AND HERITAGE STUDIES}

I would like to touch on the point that Kristiansen raises with regard to public archaeology; he characterizes public archaeology as having been more about cultural heritage or "the past in the present" and academic archaeology as having been more about "the past." Perhaps this is a distinction between European and U.S. archaeology. In the U.S. the various forms of "public archaeology" (whether in museums or public digs 
of various kinds) have very much been in the historiographical expert realm. Most often archaeologists are portrayed as scientists (alongside paleontologists). I am most often asked to speak to various schools and museums about how archaeologists conduct excavations and laboratory analyses - and about what really happened in the past. Heritage as a concept and field of research - and even as a word - in the U.S. is not well developed and understood. Archaeology outside the academy has been relegated to the field of "historical preservation" and is seen as being about the past - not about people's contemporary cultural heritage or values. I believe this is in part because of the colonial nature of U.S. history. But it is only recently that there has been increasing attention to what Randy Mason and I have termed a "social science of the past" (Chilton \& Mason 20Io). The kind of heritage studies I have developed and promoted at UMass Amherst with the Center for Heritage \& Society and the journal, Heritage \& Society, is not so much about "public archaeology" - that is, engaging with the public about what we learn from archaeology - but about why and how the past matters in contemporary society. It is a social scientific study of contemporary social behavior vis-à-vis understood pasts. As such, of course, it is not archaeology at all. And in this vein, archaeology itself is a kind of heritage practice worthy of study (see Chilton \& Silberman 20I2; Holtorf 20I2). This is very much in line with Kristiansen's call for more scientific ways of engaging with the past in the present.

To conclude on a personal note, as a child of the I960s I optimistically consider humans to be capable of using scientific and technological methods to solve any number of pressing global problems (disease, war, violence, food stress, global warming, etc.). But as a social scientist I also strongly believe that we need to first work on issues that will not be solved with data alone: social inequality, the sustainability of our natural resources, equitable decision-making and priority setting, and an understanding of the politics of science and funding mechanisms. This is certainly not a call for hyperrelativism. One of the most serious critiques of postprocessual archaeology is that it addressed "the politics of archaeology in so highly abstract a way that it provides no reference point for those archaeologists who must deal with immediate political issues" (Smith 1994). Trigger (1989:347) similarly points to the danger of hyperrelativism for those who wish to take action. In the end, Trigger's (1989:369) optimism about the future of archaeology was based on his perception that there was a "growing sense of unity and complementarity of historicism and evolutionism in Western archaeology." My own personal optimism comes from trends in archaeology, and heritage studies more broadly, to focus on problems that emanate from non-ac- 
ademic communities - community engagement and social justice, economic and social development, and environmental and cultural resource management. These types of public engagements will keep archaeology relevant, grounded, and innovative.

\section{REFERENCES}

Chilton, E. \& Mason, R. 20Io. A Call for a Social Science of the Past. Electronic Document, NSF White Paper for 'SBE 2020: Future Research in the Social, Behavioral \& Economic Sciences.' http://nsf.gov/sbe/sbe_2020/index.cfm.

Chilton, E. \& Silberman, N. 20I2. From the Editors. Heritage \& Society. Vol. 5. No. 2. Pp. I 49-I52.

Dobres, M. 1999. Of Paradigms and Ways of Seeing: Archaeological Variability as if People Mattered. In: Chilton, E. (Ed.) Material Meanings: Critical Approaches to the Interpretation of Material Culture. Pp. 7-23. Salt Lake City: University of Utah Press.

Gero, J. \& Conkey, M. I99I. (Eds). Engendering Archaeology. Oxford, UK: Basil Blackwell.

Holtorf, C. 20I 2. The Heritage of Heritage. Heritage \& Society. Vol. 5., No. 2. Pp. I53-I74.

Preucel, R. 1995. The Postprocessual Condition. Journal of Archaeological Research. Vol. 3. No. 2. Pp. I47-75.

Preucel, R. \& Mrowowski, S. 20I0. (Eds). Contemporary Archaeology in Theory: The New Pragmatism (2nd Ed). Oxford: Wiley-Blackwell.

McGuire, R. \& Paynter, R. I99I. (Eds). The Archaeology of Inequality. Oxford: Basil Blackwell.

Shanks, M. \& Tilley, C. 1987. Re-Constructing Archaeology: Theory and Practice. Cambridge, UK: Cambridge University Press.

Smith, L. I994. Heritage Management as Postprocessual Archaeology? Antiquity 68(259). Pp. 300-309.

Sweely, T. 1999. (Ed.). Manifesting Power: Gender and the Interpretation of Power in Archaeology. London: Routledge.

Trigger, B. 1989. A History of Archaeological Thought. Cambridge: Cambridge University Press.

Wylie, A. 2002. Thinking from Things: Essays in the Philosophy of Archaeology. Berkeley, CA, USA: University of California Press. 